\title{
Modelling tectonic deformation along the North-Anatolian Fault in the Sea of Marmara
}

\author{
S. Bulkan ${ }^{\mathrm{a}, *}$, P. Vannucchi ${ }^{\mathrm{b}}$, L. Gasperini $^{\mathrm{c}}$, A. Polonia ${ }^{\mathrm{c}}$, C. Cavozzi $^{\mathrm{d}}$

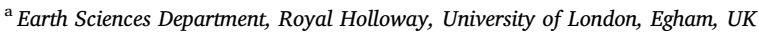 \\ ${ }^{\mathrm{b}}$ Dipartimento di Scienze della Terra, Università degli Studi di Firenze, Via La Pira, 4, Firenze, Italy \\ ${ }^{c}$ Istituto di Scienze Marine-Consiglio Nazionale delle Ricerche (ISMAR), IT-40129 Bologna, Italy \\ ${ }^{\mathrm{d}}$ NEXT - Natural and Experimental Tectonics research group, Department of Chemistry, Life Sciences and Environmental Sustainability, University of Parma, Italy
}

\section{A R T I C L E I N F O}

\section{Keywords:}

Analogue modelling

Pull-apart basins

Stress transfer

Fault orientation

Cinarcik basin

Sea of Marmara

\begin{abstract}
A B S T R A C T
Using analogue techniques, we attempted to model the complex tectonic deformation pattern observed along the North-Anatolian Fault in the Sea of Marmara from morpho-bathymetry and seismic reflection images. In particular this paper focuses on the so-called Cinarcik segment of the fault connecting the eastern Izmit segment, which entirely ruptured during the Mw 7.4, 1999 earthquake, to the western segment of the Central High. The Çınarcık segment, potentially loaded after the Izmit earthquake, is expected to rupture during an earthquake occurring in the near future, possibly the next decades, with a high potential to affect the Istanbul metropolitan area. Our analysis suggests that the development of the observed structures accommodating strike-slip, transtensional and transpressional deformations, could be explained by changes in the geometry of fault segments within a right-lateral strike-slip tectonic regime. Tectonic deformations were reproduced in the analogue model by imposing a small (about $10^{\circ}$ ) and sharp difference in the relative orientations of the strike-slip segments at the edges of a major releasing bend. In the model slower strain accumulation occurs along the analogue of the Çinarcık segment than along the analogue of the Izmit segment of the fault. This would predict a delay for earthquakes triggered by stress transfer between the Izmit and Çınarcık segments. The model further predicts that most of the deformation in the Çinarcık basin is controlled by the sharp changes in the geometry of the fault itself.
\end{abstract}

\section{Introduction}

The North Anatolian Fault (NAF) is a right-lateral, $>1200 \mathrm{~km}-$ long continental transform fault that separates the Eurasian and Anatolian plates (Fig. 1) (Şengör et al., 2005). In its eastern part, the NAF is constituted by a single fault strand that experiences almost pure strikeslip deformation. To the west, it separates into two major branches, the Northern branch (N-NAF) and the Southern branch (S-NAF) (Fig. 1) that accommodate predominantly transtensive deformation. According to GPS modelling, the northernmost of these branches (NAF-N in Fig. 1) takes up most Eurasian-Anatolian relative motion, about $24 \pm 1 \mathrm{~mm} /$ yr (McClusky et al., 2003). Geodynamic models explain the transtension pattern observed in the Marmara basin as a consequence of Anatolia escaping towards the west, with its rate of counterclockwise rotation progressively increasing westward in response to the Hellenic subduction (McClusky et al., 2000). The NAF-N pull-apart system of the Sea of Marmara creates deep tectonic depressions that reach over
$1200 \mathrm{~m}$ below sea level, separated by structural highs (Fig. 1). Despite the formation of the Sea of Marmara being elegantly explained as a consequence of major oversteps along the westward propagating NAF (Barka and Kadinsky-Cade, 1988; Armijo et al., 1999; Şengör et al., 2005), there remain unsolved issues regarding its recent tectonic evolution and present activity, issues that are particularly critical for reliable earthquake scenarios in a region of high seismic hazard. According to historical catalogues (Ambraseys, 2002) the Sea of Marmara and other adjacent regions along the NAF are sites of major earthquakes ( $\mathrm{Mw} \geq 7$ ) with a rather regular periodicity of about $250-300$ years along specific fault segments. The delimitation of these segments and analysis of their mutual interaction through time is particularly complex in the Sea of Marmara due the presence of releasing and restraining bends. This structural complexity has led to contrasting interpretations. Existing models assume: (1) the presence of a single through-going fault (Le Pichon et al., 2001); (2) a sequence of pull-apart basins with northwest-trending normal faults and ENE-trending strike-slip faults

\footnotetext{
* Corresponding author.

E-mail address: Sibel.Bulkan.2015@live.rhul.ac.uk (S. Bulkan).
} 


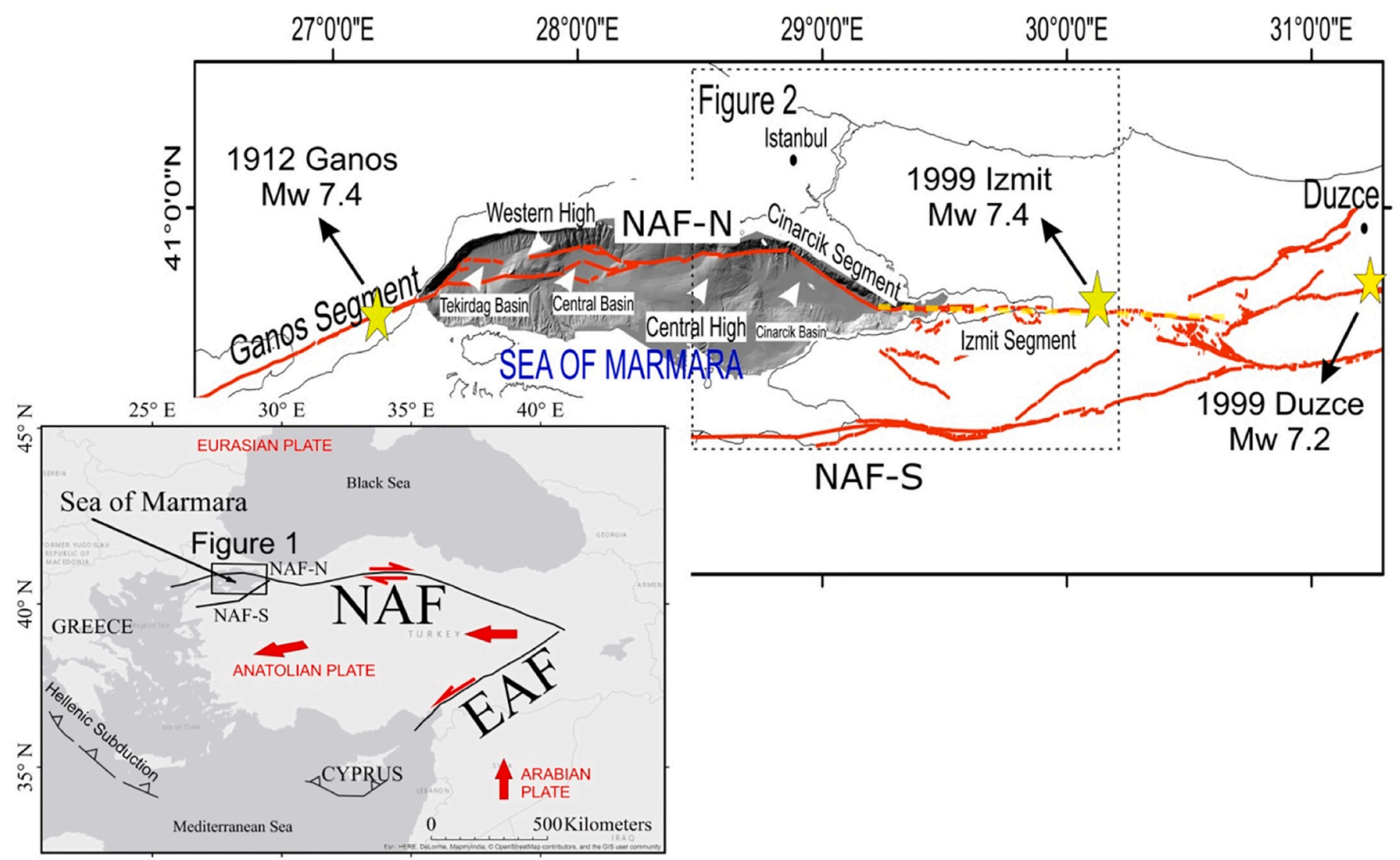

Fig. 1. Tectonic map of the Sea of Marmara region (modified from Le Pichon et al., 2003; Gasperini et al., 2011a; Grall et al., 2012, 2013). Stars show locations of earthquake epicentres. Dotted line in yellow shows the surface rupture of the 1999 Izmit earthquake as estimated from its aftershock locations. Black dotted box shows the area of the map displayed in Fig. 2. The lower inset highlights the main regional tectonic elements in this area. (For interpretation of the references to colour in this figure legend, the reader is referred to the web version of this article.)

(Armijo et al., 2002); or (3) a major negative flower structure (Laigle et al., 2008). Models of seismic hazard depend strongly on the assumed tectonic model because the length of potentially rupturing seismogenic segments differs significantly between the different model reconstructions.

Here we focus on structural analysis of the Cinarcik Basin, the easternmost deep basin (about $1200 \mathrm{~m}$ ) in the Sea of Marmara. The basin is bounded to the north by the so called Cinarcik segment of the NAF-N that connects the Izmit segment to the east with the Central High to the west (Fig. 2). This segment is inferred to have been tectonically loaded by the $1999 \mathrm{Mw}=7.4$ Izmit earthquake which ruptured the fault through the entire Gulf of Izmit (Gasperini et al., 2011a). For this reason, describing the position and geometry of active faults and reconstructing their recent deformation history can provide key information for reliable seismic risk scenarios in the Istanbul metropolitan area.

In particular, our work will address the following topics:

1) Can restraining and releasing bends along a transcurrent-type fault act as barriers to stress transfer and earthquake slip? Or do they help earthquake propagation, as suggested by Cunningham and Mann (2007)?

2) Does co-seismic strain release on the Izmit segment directly affect strain accumulation on the Cinarcik segment?

3) Since the Izmit segment is (and has been) oriented at an angle relative to the Central High segment towards the west (about $10^{\circ}$ ), could this difference be responsible for the compressive deformation observed at the NW edge of the Cinarcik basin?
To analyse these problems, we used a 3D scaled sandbox model which reproduced the NAF-N segmentation as imaged by geophysical data, i.e., by morphobathymetry and seismic reflection profiles across the Cinarcik Basin. Our model experiment was successful in reproducing observed deformation patterns along the basin, and therefore the eastern part of the NAF-N, and gives us insights on possible stress transfer mechanisms between fault segments near the Istanbul metropolitan area.

\section{Tectonic setting}

The Cinarcik basin is the easternmost sub-basin of the Sea of Marmara, located $\sim 20 \mathrm{~km}$ to the southeast of Istanbul (Fig. 1). It is about $50 \mathrm{kmlong}, 18 \mathrm{~km}$ wide, and reaches a maximum depth of $1270 \mathrm{~m}$. The basin is positioned on the extensional side of the prominent Tuzla fault bend (Fig. 2). A second major bend, the Istanbul bend, connects the Cinarcik basin with the Central High segment to the west (Fig. 2).

Seismic reflection profiles indicate that the southern and the northern margins of the Cinarcik basin accommodate a large amount of extension, and that the master fault creating the asymmetric basinforming depression is located along its northern edge (Okay et al., 2004; Seeber et al., 2004, 2006; Carton et al., 2007; Sorlien et al., 2012). These studies also show that the main basin depocenter gradually migrated to the east following the development of the master fault, which coincides with the NAF-N principal displacement zone and it is known as the Cinarcik Segment (Le Pichon et al., 2001). Tectonic reconstructions assume that the basin depocenter grew by propagating from the west $\approx 2.5-1.5 \mathrm{Ma}$, and reached its present location at $\approx 1 \mathrm{Ma}$ 


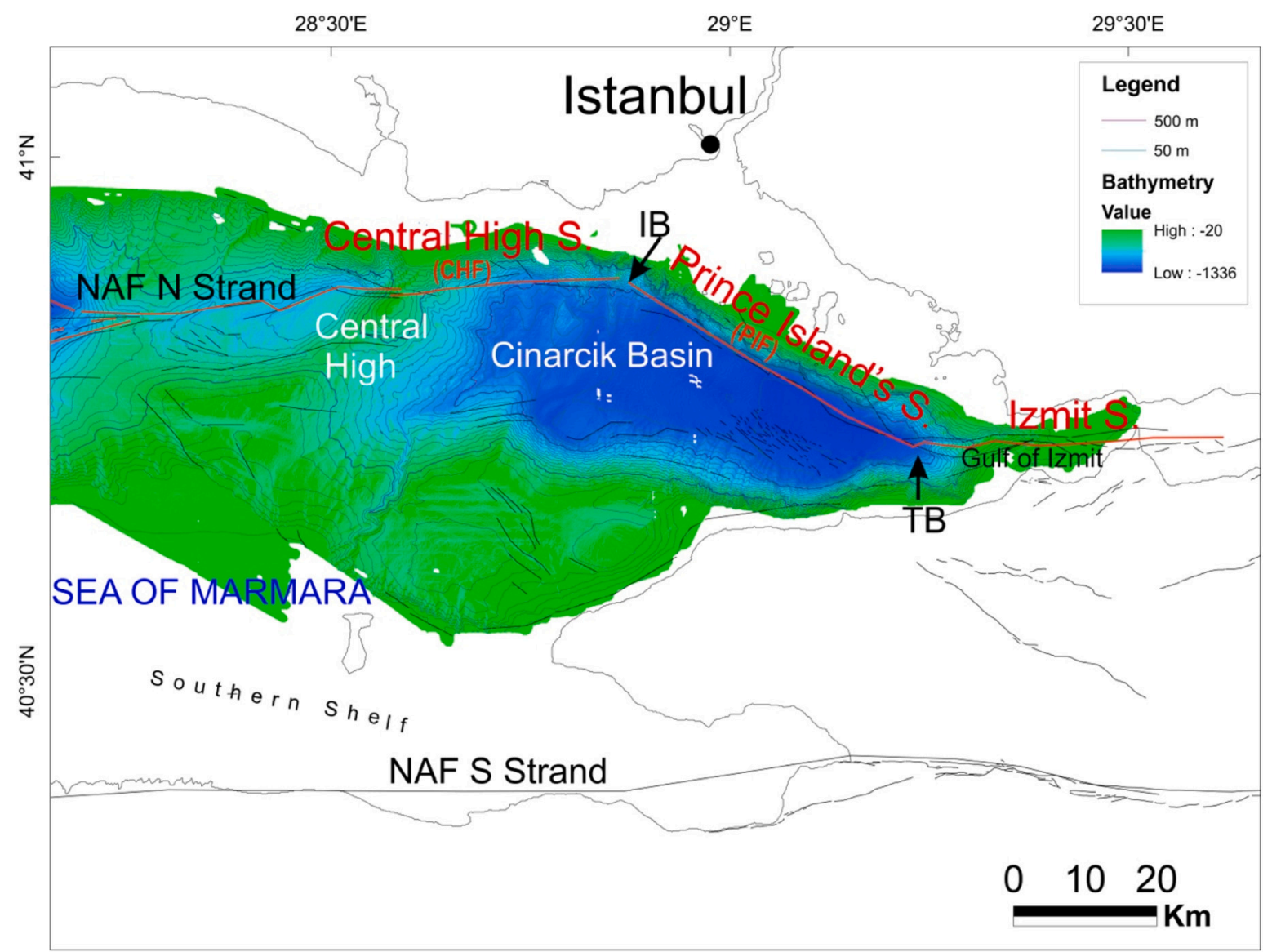

Fig. 2. Tectonic setting of the Cinarcik Basin. Faults modified from Le Pichon et al., 2003; Gasperini et al., 2011a; Grall et al., 2012, 2013. The major fault is highlighted in red. Thin lines represent the isobath lines for every $50 \mathrm{~m}$ and $500 \mathrm{~m}$. IB and TB represent the Istanbul Bend and Tuzla Bend, respectively. (For interpretation of the references to colour in this figure legend, the reader is referred to the web version of this article.)

(Carton et al., 2007; Sorlien et al., 2012; Kurt et al., 2013) (Fig. 2). This evolution is recorded in the 4-6 km-thick sediment fill (Carton et al., 2007) which shows a marked asymmetry towards the Gulf of Izmit, where the basin narrows (Okay et al., 2004).

The active NW-SE trending fault bordering the basin to the north corresponds to a steep scarp cut by canyons that can reach $12 \mathrm{~km}$ in length, affected by scars of submarine landslides up to 2.5 to $4 \mathrm{~km}$ wide. A major landslide affecting the NE edge of the basin, activated in the upper Pleistocene, was interpreted as being triggered by one or more earthquakes along the NAF (Görür and Çağatay, 2010; Özeren et al., 2010). To the south, the Cinarcik basin is bounded by an antithetic set of en-echelon normal faults that trend subparallel to the NAF-N (Fig. 2) (Smith et al., 1995; Le Pichon et al., 2001; Armijo et al., 2002). Bécel et al. (2010) observed that this low angle normal fault system connects to a transtensional zone towards the south which seems to have accommodated early Pliocene stretching. In the central part of the basin another fault system joins the Izmit segment (Carton et al., 2007; Grall et al., 2012).

The tectonics of the Cinarcik basin has been interpreted in the frame of the overall Sea of Marmara geologic setting, following several models. Armijo et al. (2002) considered the basin to be a wedge-shaped transtensional basin that formed across a large releasing step-over of the main strike-slip fault zone. Other models (e.g., Laigle et al., 2008) assume that the general architecture and lateral heterogeneities below the Cinarcik basin are caused by inherited basement structures with numerous faulted and tilted upper crustal blocks. These bounding block faults seem to penetrate to a maximum depth of $6 \mathrm{~km}$ below the seafloor (Bécel et al., 2009, 2010). In all these models, the Cinarcik basin formed at a bend in the NAF and basin subsidence was due to oblique slip on a steeply-dipping, non-vertical transform fault (Seeber et al., 2006, 2010). Thus, fault geometry, potentially inherited from pre-existing sutures, controls the kinematics of the faults in the basin, and is critical for modelling their seismogenic behavior (Seeber et al., 2006).

Seismically, the Cinarcik basin is located in a key area. Since 1939, the NAF has been site of seven $M>7$ earthquakes, following a sequence which originated in eastern Anatolia and propagated to the west towards Istanbul. The most recent earthquake, the 1999 Mw7.4 Izmit event, ruptured a segment of the NAF-N at the eastern end of the Sea of Marmara (Gasperini et al., 2011b). The Ganos segment, at the opposite western end of the Sea of Marmara, was the site of a Mw 7.4 earthquake in 1912 (Fig. 1). The most recent event occurring along the Cinarcik segment and affecting the Istanbul metropolitan area is a Ms. $=6.4$ event in 1963 - recently re-evaluated by Baştürk and Meral Ozel, 2020. This seismic sequence leaves a seismic gap along the $150 \mathrm{~km}$-long NAF$\mathrm{N}$ segment cutting through the Cinarcik basin between the Prince Islands Fault (PIF) and the Central High Fault (CHF) (Bohnhoff et al., 2013; Ergintav et al., 2014). This gap is located only $40 \mathrm{~km}$ southeast of Istanbul, with a potential for earthquakes estimated to be $\mathrm{M}=7$ or higher (Parsons et al., 2000; Parsons, 2004; Bohnhoff et al., 2013). The earthquake fault slip in the 1999 Izmit earthquake is assumed to have increased the elastic strain accumulation on the adjacent segment towards the west (Parsons et al., 2000; Hubert-Ferrari et al., 2000; Uçarkuş et al., 2011; Gasperini et al., 2011b; Bohnhoff et al., 2013) which is considered locked to a depth of $\sim 10 \mathrm{~km}$ accumulating the slip deficit (Bohnhoff et al., 2013). At the surface of the 1999 Izmit rupture zone, however, the observed current maximum creep rate is $8 \mathrm{~mm} / \mathrm{yr}$ (Çakir et al., 2012; Aslan et al., 2019). 

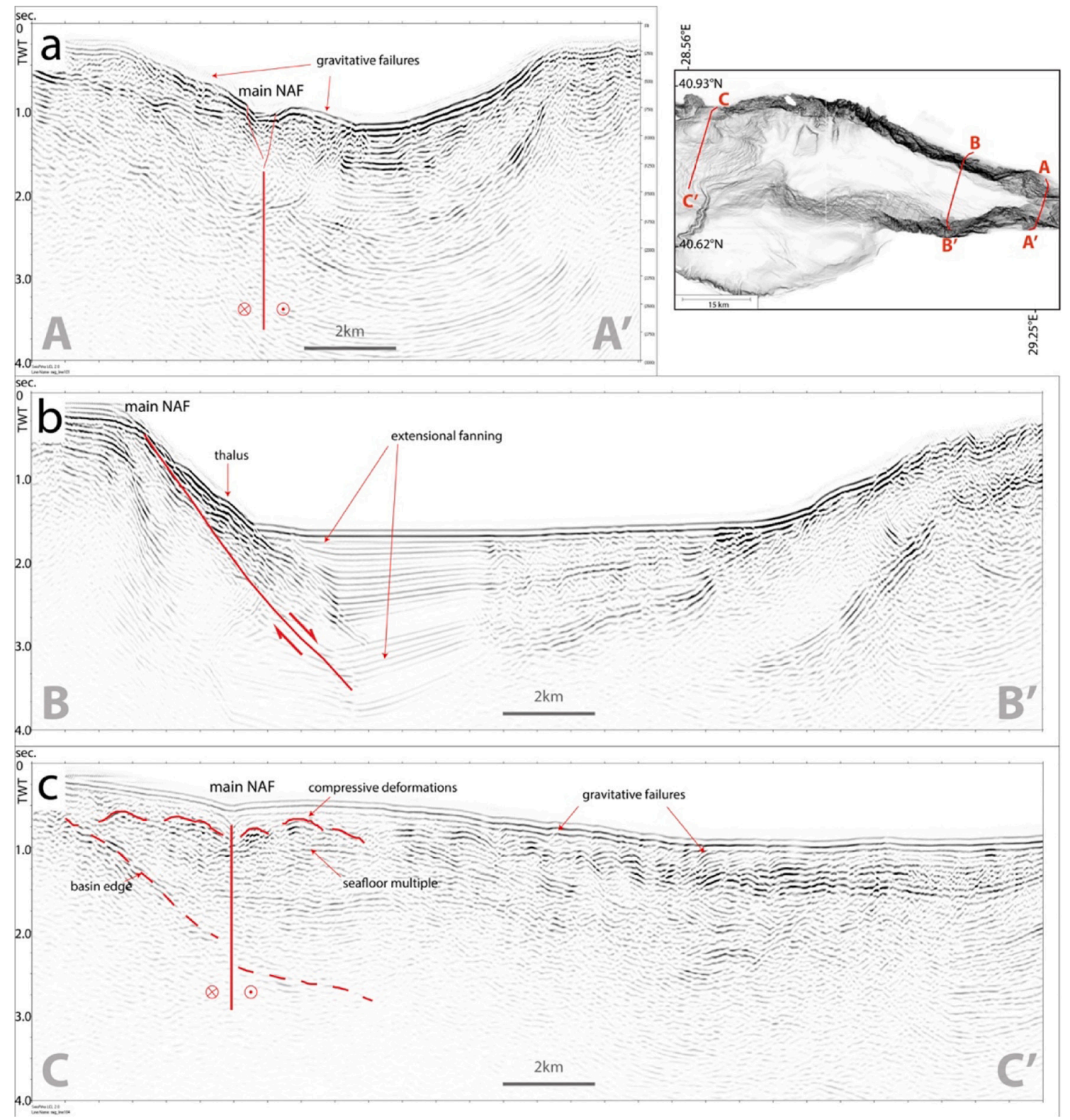

Fig. 3. Seismic profiles across the Cinarcik Basin. a) Line 101 (section A-A') located immediately E of the Tuzla Bend; b) Line 122 (section B-B'), crossing the central part of the Cinarcik basin; c) Line 184 (section CC') cutting across the NAF trace to the west the Istanbul Bend. All seismic reflection profiles were collected during the SEISMARMARA cruise (Hirn and Singh, 2001; Carton et al., 2007).

\subsection{Cross-sectional geometries of the Cinarcik basin}

We used a set of seismic reflection profiles collected in the Cinarcik basin during the SEISMARMARA cruise (Hirn and Singh, 2001) to characterize tectonic deformation along the NAF in this region, and to compare to results from analogue modelling. The SEISMARMARA seismic lines were collected onboard of the R/V Nadir using a $4.5 \mathrm{~km}$ long streamer and an airgun source. These dataset has been used by Carton et al. (2007) to reconstruct the three-dimensional structure and seismostratigraphy of the Cinarcik basin, and to infer its geological evolution. Most of the seismic lines cut orthogonally across the northern shelf of the Cinarcik basin from $28.4^{\circ} \mathrm{E}$ to $29.3^{\circ} \mathrm{E}$, crossing the principal deformation zone of the NAF-N (Fig. 3). Geophysical data presented here consists of time-migrated sections that were filtered and plotted using SeisPrho (Gasperini and Stanghellini, 2009) to produce geo-referenced bitmaps that were used for data interpretation and linedrawings.

In this study we focus on three seismic sections: 1) Line 101, in the eastern part of the basin, to the east of the Tuzla Bend; 2) Line 122, in the central part of the Cinarcik basin; 3) Line 184, which cuts across the NAF-N immediately to the west of the Istanbul Bend.

Line 101 (section A-A', Fig. 3a) to the west of the Izmit Gulf highlights the presence of a narrow sub-vertical deformation zone that corresponds to the main strand of the NAF-N. We interpret this pattern as diagnostic of almost pure strike-slip deformation. The minor features that 'deform' the seafloor are probably related to gravity failures caused by co-seismic shaking during large magnitude earthquakes.

Moving to the centre of the basin, seismic Line 122 (section B-B', Fig. 3b) shows the presence of growth structures and fanning of the sediment packages towards the NNE, suggesting the presence of extensional/transtensional syn-depositional deformation. The main fault trace extends across the continental shelf and slope which constitute the footwall of an extensional/transtensional fault, that vertically displaces the seafloor by more than $1 \mathrm{~km}$ (Fig. 3b). This deformation pattern characterizes the Cinarcik segment of the NAF-N from $29.10^{\circ}$ to $28.8^{\circ} \mathrm{E}$, where the morphobathymetric data show a sharp change in the NAF-N's 
orientation from $300^{\circ} \mathrm{N}$ to $270^{\circ} \mathrm{N}$.

At the western end of the basin, the shelf margin bends again towards $255^{\circ} \mathrm{N}$ and shows a rectilinear shape clearly controlled by tectonic deformation (Fig. 3b). Line 184 (section C-C' in Fig. 3c) shows a composite deformation pattern. To the north, a high-amplitude reflector, probably marking the acoustic basement's top (basin edge in Fig. 6), is displaced by a sub-vertical fault showing a clear topographic expression. This structure, characterised by strike-slip kinematics, coincides with the present-day principal displacement zone of the $\mathrm{NAF}-\mathrm{N}$, (Fig. 3c). Between the high-amplitude reflector and the vertical fault, reflectors are folded and pervasively deformed by compressive deformation. This pattern is probably the effect of transpressive stresses, active in the past and subsequently replaced by almost pure strike-slip displacement along the sub-vertical NAF-N trace. This interpretation seems to be confirmed by the presence of more recent gravitative/extensional failures along the slope that mark the slumping and dismantling of the topographic high through mass-wasting towards the basin depocenter.

\section{Analogue models: setup and material}

The analogue model experiments described in this paper were designed to simulate the eastern portion of the NAF-N in the Sea of Marmara, and to obtain further insights on the relationships between the present segmentation and the evolution of the major fault (Fig. 2). In particular we focussed on how the different orientations of the fault segments can influence the kinematics of the pull-apart basin and the propagation of strain in a dextral transtensional regime. Model results were compared with marine geophysical data that includes a multibeam echosounder morpho-bathymetric map collected by IFREMER in 2000 (Le Pichon et al., 2001) and a set of multichannel seismic reflection profiles collected during the SEISMARMARA cruise (Hirn and Singh, 2001) described in the previous section.

The experimental apparatus consisted of a sandbox with a $250 \times 100 \mathrm{~cm}$ glass basal plate, equipped with one computer-controlled motor, and a "structured" light scanner to monitor the topographic surface of the model with a resolution of $0.71 \mathrm{~mm}$ in the $\mathrm{x}$ and $\mathrm{y}$ directions. In structured light scanning, also known as "point cloud" mapping, a pattern (e.g., a grid of dots) is projected onto the surface to be scanned. The distortion of this grid is then used to reconstruct the surface's relief. This provides an effective tool to comprehensively measure model uplift and subsidence. This method allows for high precision quantitative measurements of deformation (e.g., Nestola et al., 2013; D'Adda et al., 2017). The evolution of the model was recorded using an overhead NIKON-D5200 digital with $6000 \times 4000$ pixel resolution, while a free to move secondary camera was dedicated to photograph cross sections. In this experimental programme, the overhead camera captured images and the structured light scanning provided elevation data every $20 \mathrm{~min}$, corresponding to $5 \mathrm{~mm}$ increments of basal plate displacement. Experiments were performed using a $1 \mathrm{~mm}$-thick Plexiglas mobile plate that was properly cut to reproduce a simplified geometry of the NAF-N in the study area (Fig. 4).

The base plate was cut with a $14 \mathrm{~cm}$ length releasing bend adjacent to a $9 \mathrm{~cm}$ restraining bend which form an angle of $10^{\circ}$ (Fig. 4). This cut constitutes the "basal fault" of the model. Dextral shear was imposed onto the mobile plate by translating it at a constant displacement rate of $2 \mathrm{~cm} / \mathrm{h}$, for a total displacement of $7 \mathrm{~cm}$. The scaling factor of the models was $2 \times 10^{-6}(1 \mathrm{~cm}$ per $5 \mathrm{~km})$ : the $15 \mathrm{~km}$-thick upper crust (Kende et al., 2017) was reproduced by a $1.5 \mathrm{~cm}$-thick sand pack, while $0.2 \mathrm{~cm}$ of silicone represented the ductile lower crust. Serial cross sections with $0.5 \mathrm{~cm}$ spacing were cut at the end of the experiments after wetting the models with tap water and waiting $24 \mathrm{~h}$ to ensure complete imbibition. The brittle upper crust was simulated with a $1.5 \mathrm{~cm}$-thick sand pack consisting of six $0.2 \mathrm{~cm}$-thick alternating white and coloured quartz sand layers. Density of the sieved sand was $1.670 \mathrm{~g} / \mathrm{cm}^{3}$ and the mean quartz grain size was $224 \mathrm{\eta m}$. The angle of internal friction was $33^{\circ}$ and cohesion at peak was $102 \mathrm{~Pa}$ (see Table 1) (e.g., D'Adda et al., 2016). To simulate the mechanical displacement of the viscous lower crust, a basal layer of PDMS XIAMETER silicone putty mixed with barite powder was placed at the base of the sand pack, resulting in a thickness of $0.1 \mathrm{~cm}$ on the moving plate and $0.2 \mathrm{~cm}$ on the basal plate (orange layer in Fig. 5). The density of this layer was $1.15 \mathrm{~g} /$ $\mathrm{cm}^{3}$ and the dynamic shear viscosity was $1.4 \times 10^{4} \mathrm{~Pa}$-s.

\subsection{Particle image velocimetry (PIV)}

Particle Image Velocimetry allows for compilation of displacement/ velocity map through measurements of particle displacements across the sand surface between successive photographs (White et al., 2001; Adam et al., 2002; Adam et al., 2005; Wolf et al., 2003), here taken every 4 mins during the experiment. It reveals where, how and when deformation occurs in the model.

Here we use interrogation areas of pairs of images in $64 \times 64$ and $32 \times 32$ pixel subregions gathered from 146 images to derive the bestfit particle displacement in the interrogation areas through use of the cross-correlation method implemented in the free MATLAB-based PIVLab Software package (Thielicke and Stamhuis, 2014). This led us to obtain a velocity field from incremental particle displacements at any the time frame. Incremental shear rates, shear strains and rates of topographic change were calculated using an open-source code (see Bulkan, 2020; https://doi.org/10.5281/zenodo.3597335) to sample the material derivative of the finer topographic grid. It uses the velocity gradient matrix created by measuring the derivatives of the $u$ and $v$ velocity components in the $x$ and $y$ directions (Eq. (1)) $\Delta V$ represents the velocity gradient matrix:

$\Delta V=\left[\begin{array}{lll}\partial u / \partial x & \partial u / \partial y & \partial u / \partial z \\ \partial v / \partial x & \partial v / \partial y & \partial v / \partial z\end{array}\right]$

The incremental horizontal shear rate is approximated to be a velocity gradient perpendicular to the velocity discontinuity applied at the base of the model $(\partial u / \partial y)$.

The areal strain is the sum of the diagonal components of $\Delta V$ $\left(E_{x x}+E_{y y}\right)$ :

$E_{x x}+E_{y y}=\partial u / \partial x+\partial v / \partial y$

The code calculates incremental rates of topographic changes by subtracting the measured topography at time $n-1$ from topography at time $n$, corrected for any displacement between times $n-1$ and $n$. Specifically, the material derivative of topography is determined, i.e., the change in topography over a time-step that follows the motion at the surface. To do this, the software measures the relief on the finer mesh of points at each model step, and uses an interpolation of the velocity field determined from the coarser mesh of PIV sampling subregions to backtrack each sample point on the fine mesh to where it started from at the end of the previous time step. The difference between these measurements is the change in relief of this surface point over the time step. Rates of incremental topographic changes are then related to the incremental strain patterns in order to understand how relief is generated. Shear rate maps estimate the amount of shear deformation during each step of the model, while areal strain maps show the rates of extension and compression in each area.

\section{Experimental results}

\subsection{Cross-sections}

The setup geometry imposed to the model fault generated through transtensional and transpressional deformation with distributed and focused patterns that follow the along-strike segmentation of the fault. This is visible in the 3D perspective view of the final model step, after $7 \mathrm{~cm}$ of cumulative displacement (Fig. 6). Overall, the basin topography 

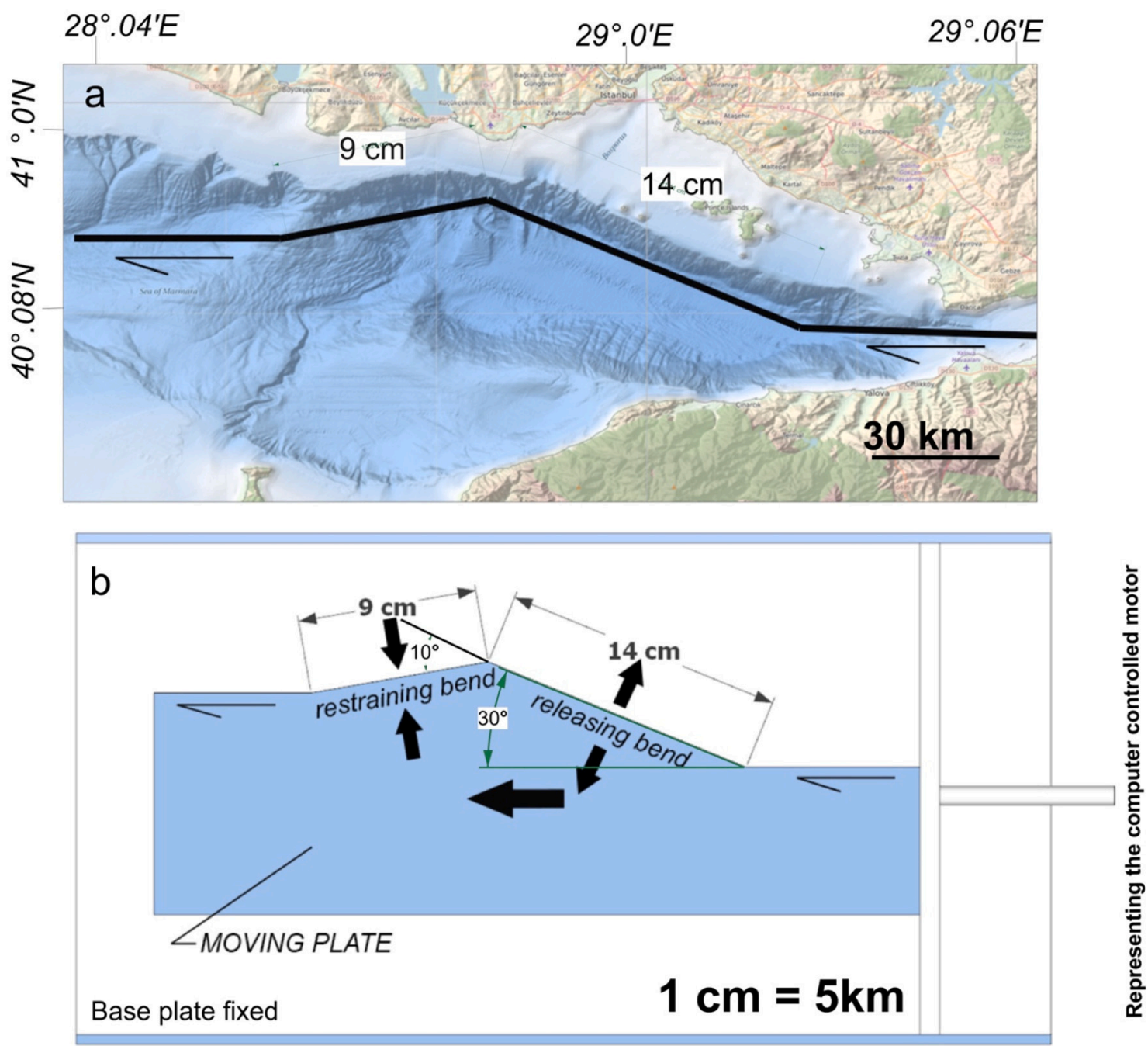

Fig. 4. a) Geometrical setting of the plate boundary in the study area reproduced using a plexiglas-moving plate. b) Plan view of the setup a the initial pre-cut step including analogue scaled lengths. The piston on the right represents the computer-controlled motor within the system.

Table 1

Mechanical and physical properties of the materials used in the model.

\begin{tabular}{llllll}
\hline Materials & Density $\left(\mathrm{g} / \mathrm{cm}^{3}\right)$ & Mean grain size $(\eta \mathrm{m})$ & Cohesion at peak $(\mathrm{Pa})$ & Angle of internal friction $\varphi$ & Dynamic shear viscosity $\eta($ Pa $\mathrm{s})$ \\
\hline Sand $^{\mathrm{a}}$ & 1.670 & 224 & 102 & $33^{\circ}$ & - \\
Silicone $^{\circ}$ barite $^{\mathrm{b}}$ & 1.150 & - & - & - & $1,4 \times 10^{4}$ \\
\hline
\end{tabular}

${ }^{\text {a }}$ Upper crust (from Klinkmüller et al., 2016).

b Weak lower crust (from Cappelletti et al., 2013).

shows a graben corresponding to the Cinarcik basin depocenter, and the development of a topographic high at the western end of the basin, in correspondence with the Istanbul Bend. The graben forms as an asymmetric pull-apart basin narrowing towards the eastern (right) side, with the deepest area localised in the centre of the basin (Fig. 6). From east to west, the deformation pattern shows the along-strike development of three systems with different fault characters and associated relief: 1) almost pure strike-slip with neutral relief; 2) transtension and negative topography; 3 ) transpression and high positive relief.

The final model state was cut along eighteen profiles to provide vertical cross- sections displaying the internal geometry within the block. Variability in the deformation patterns is represented by three profiles including pure strike-slip deformation, transtension, and transpression (Figs. 6 and 7).

Section 1 represents modelled deformations in the easternmost region. The close-up view of Fig. 7a shows that deformation in this region is accommodated by a main sub vertical strike-slip fault that cuts through the lower crust (silicon putty), with this fault being bounded by a series of secondary faults that accommodate transtensive deformation. The normal component of displacement taken up by secondary faults is responsible for the development of a narrow asymmetric depression.

Proceeding towards the basin centre, Section 2 (Fig. 7b) highlights the presence of extensional deformation (with a minor strike-slip component) that creates a topographic depression cutting through the entire lower crust putty. The extensional stress generates a wide graben controlled by a series of domino faults and rollover anticlines. Deformation is mainly controlled by a main fault located to the north of the basin and dipping towards the south, corresponding to the NAF-N principal displacement zone. This fault that follows the weak zone with 


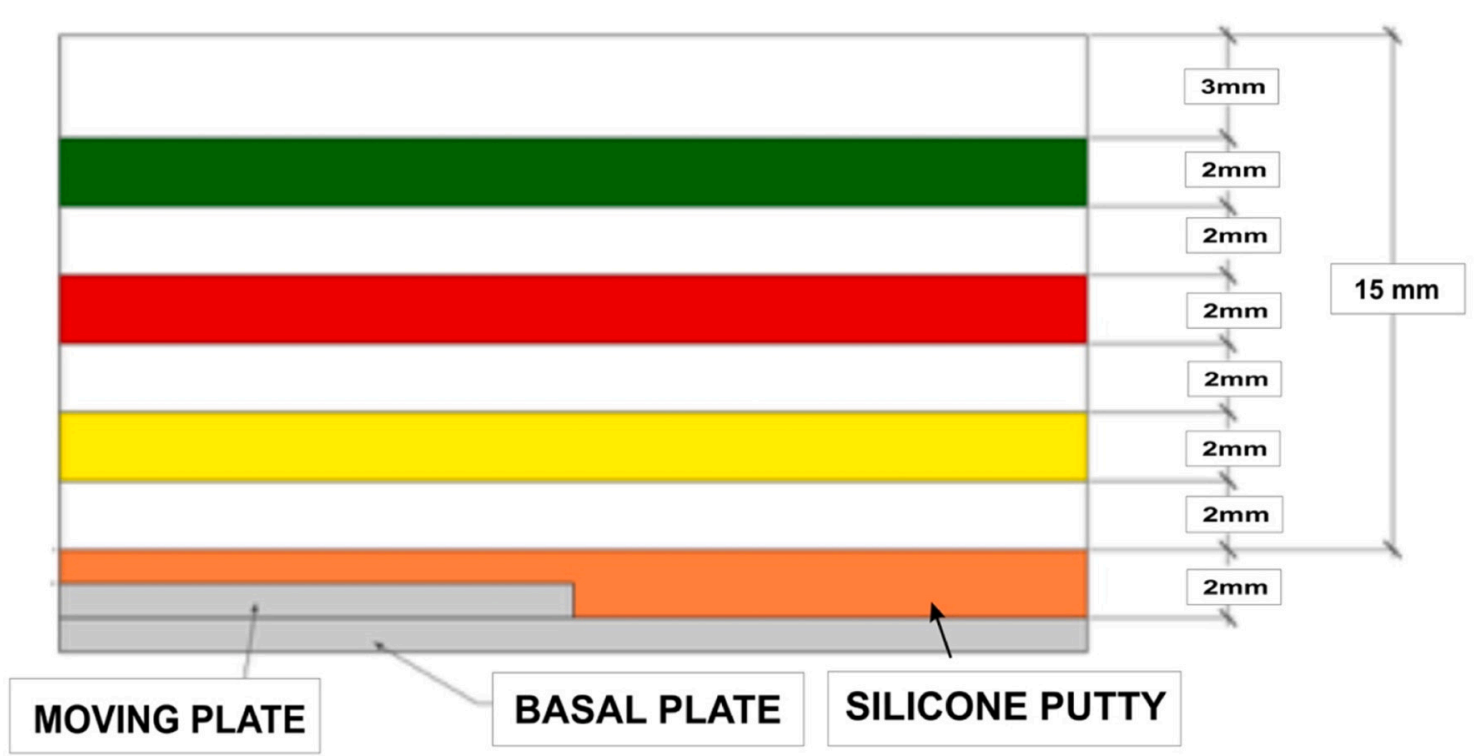

Fig. 5. Initial stratigraphy chosen for the experiment. The multilayer is formed by a basal plate topped by a purposely cut, $1 \mathrm{~mm}$-thick plexiglass plate able to move, overlaid by silicon putty reaching a maximum thickness of $2 \mathrm{~mm}$. Six $2 \mathrm{~mm}$-thick sand layers topped by a $3 \mathrm{~mm}$-thick layer complete the setup.

the thinned silicone putty is bounded by synthetic and antithetic secondary faults (Fig. 7b).

To the west of the model, Section 3 (Fig. 7c) shows folding of the layers to form a gentle transpressional pop-up structure in the north that is cut by a master fault and by secondary faults. Here the master fault is almost vertical, and the dextral strike-slip motion appears localised, analogous to the behavior of the NAF main track in this region. The lower crust silicone putty was mobilized by deformation, resulting

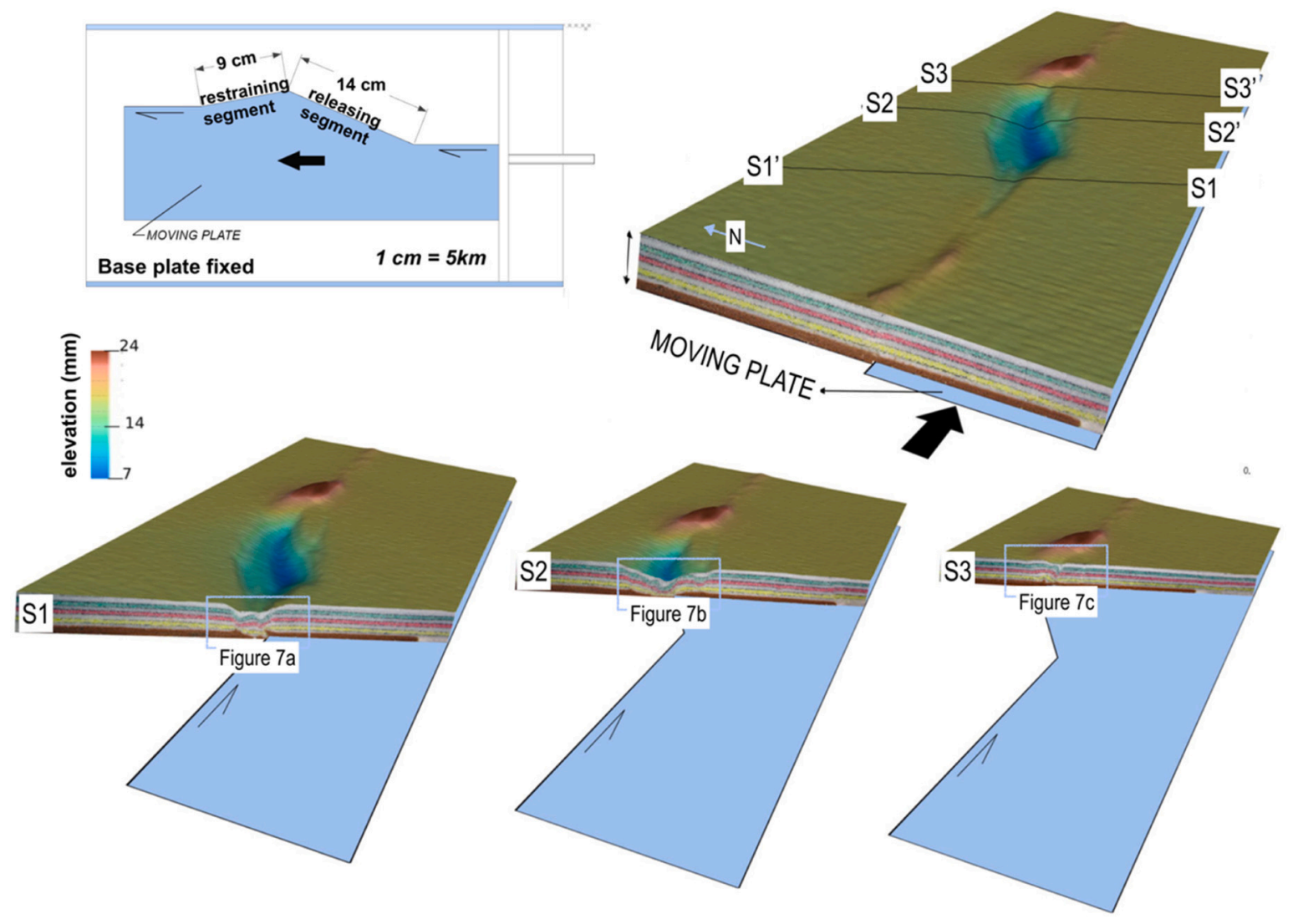

Fig. 6. Results of the analogue modelling experiment. 3D view of the last deformation step after $7 \mathrm{~cm}$ of total deformation with areas of uplift and subsidence highlighted by a colour pattern (red = uplift; blue = subsidence; green = neutral). Key sections chosen as representative of the overall deformation pattern are also indicated (see close up views in Fig. 7). Photographs are complemented by laser scan images of the model surfaces observe the total subsidence and interpreted faults. Blue arrow points north. The left top image shows the initial model setup. (For interpretation of the references to colour in this figure legend, the reader is referred to the web version of this article.) 


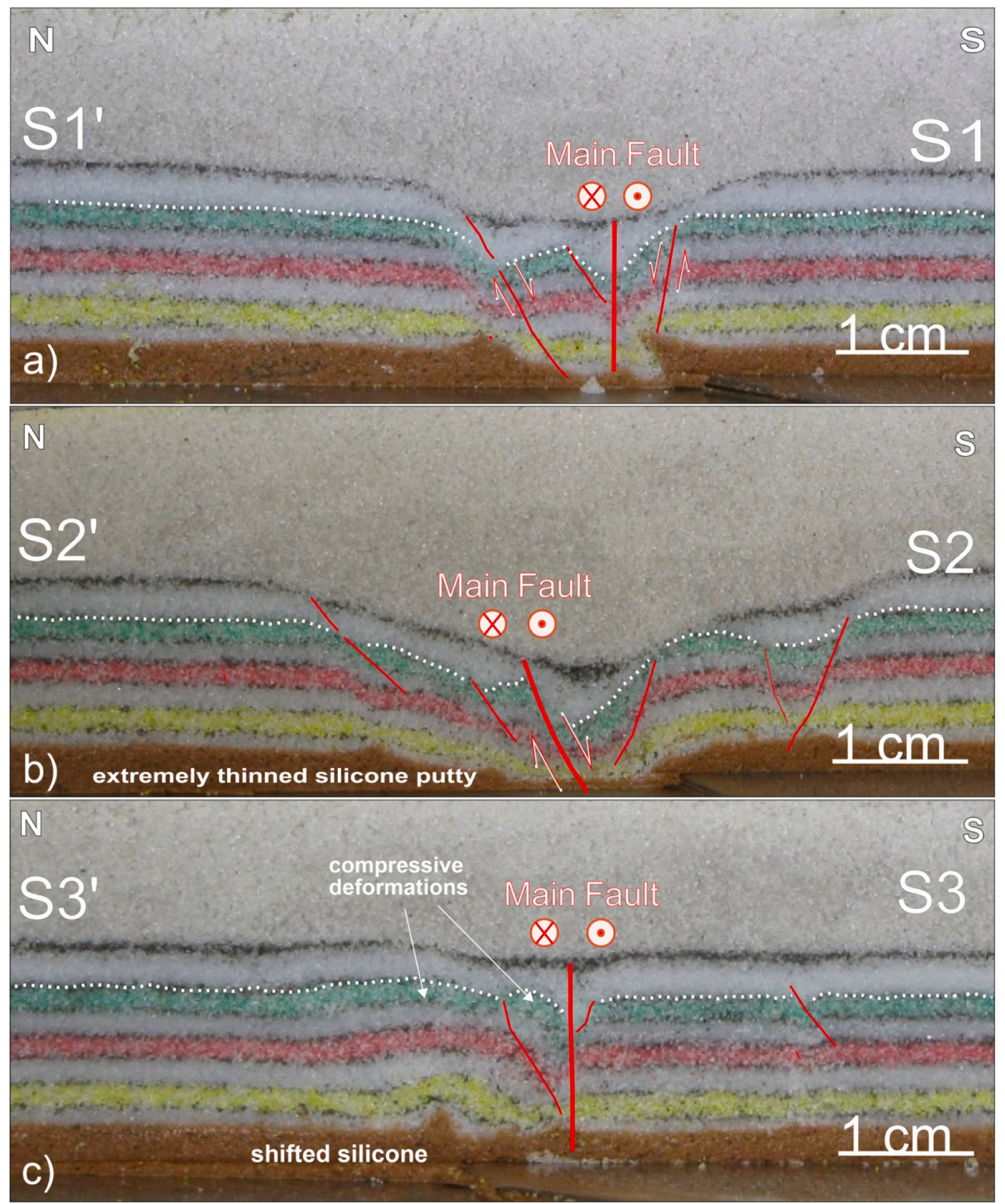

Fig. 7. Close-up views of the fault trace in the cross sections presented in Fig. 6. The coloured sand packages represent sediments layers in the upper crust, each layer is $2 \mathrm{~mm}$ thick. The upper $3 \mathrm{~mm}$-thick white layer was applied after the experiment was run to preserve the developed structures. The orange silicone putty represents the lower crust.

in a shift and protrusion at the base of the folded layers. Despite compression and uplift of the layers, the secondary faults show a normal component. These secondary faults are present only to the south of the master faults, and show decreasing dip angles and increasing displacements as they approach the master fault (Fig. 7c).

To summarize, the simple initial geometry imposed to the model was able to reproduce a deformation pattern similar to that observed in the Cinarcik basin, both in term of basin geometries and the fault deformation patterns observed in the seismic reflection profiles.

\subsection{Tectonic strain and topography}

Segmentation of the NAF-N is responsible for oversteps and changes in fault orientation at both ends of the Cinarcik basin. To understand how these geometries can influence strain accumulation and propagation during and after major earthquakes, we analysed the evolution of the incremental shear rate over the course of our experiment. Fig. 8 shows three phases of deformation corresponding to increasing displacement along the basal fault. Shear rate, topographic change and areal strain portray how intensity and velocity of deformation is distributed and how they are translated into permanent deformation. 


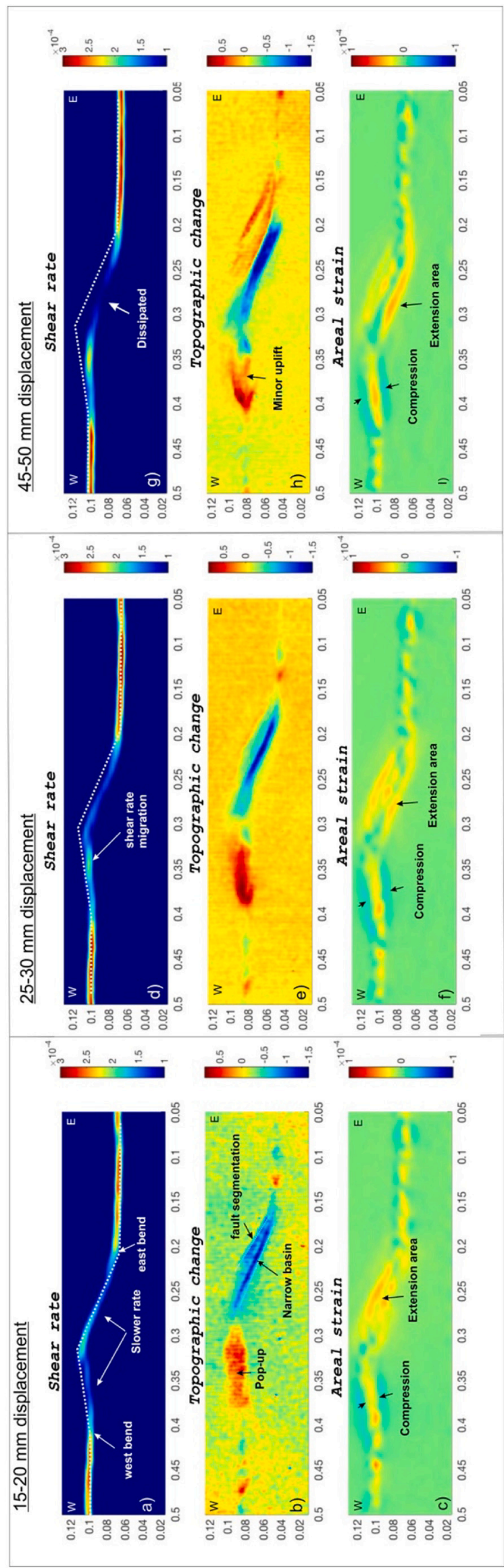

Fig. 8. Comparison of shear rate, topographic change, and areal strain during three phases of the progressive deformation: between 15 and $20 \mathrm{~mm}(\mathrm{a}, \mathrm{b}, \mathrm{c})$; 25-30 mm (d,e,f); and 45-50 mm (g,h,i), of displacement. Shear rate unit is 1/ $\mathrm{m}$, areal strain is dimensionless $(\mathrm{m} / \mathrm{m})$. In the figure panels, blue refers to low shear rates, negative topographic changes and compression, while red refers to high shear rates, positive topographic changes and extension, respectively. See text for details. (For interpretation of the references to colour in this figure legend, the reader is referred to the web version of this article.)

Elastic strain accumulation is not directly calculated.

Initially, between 15 and $20 \mathrm{~mm}$ of basal displacement, the imposed shear is transferred from the $E$-W segments of the fault to the releasingrestraining pair, but deformation there seems much slower (Fig. 8a). The eastern and the western fault bends are nodal points where the strain rate dramatically changes. Model topography shows that the releasing-restraining sectors accumulate most of the permanent deformation, both transtensive and transpressive. The apparent slower deformation possibly implies a diffuse vs. concentrated shear distribution. However, to the east of the eastern bend (corresponding to the Tuzla Bend) and to the west of the western bend (corresponding to the Istanbul Bend) the presence of high relief coincident with shear maxima suggest that shear stress is not completely transferred, and permanent deformation is a direct effect of fault segmentation (Fig. 8b). Interestingly, the restraining bend is characterised by compressional strain at the edge of the uplifted area, while extension is present along the central fault trace within the compressional region (Fig. 8b, c). The same pattern is visible between 25 and $30 \mathrm{~mm}$ of displacement, when the high shear rate of the eastern east-west segment drops at the releasing bend more than it did earlier, while the shear rate increases more strongly across the restraining bend (Fig. 8d). Associated with these changes in shear rate, the topographic change seems to slowly migrate towards the west (Fig. 8e). The strain pattern of compression and extension only partially corresponds to the observed uplift and subsidence. In fact, the extensional deformation on the releasing bend becomes wider and is distributed into three separate zones (Fig. 8f). Between 45 and $50 \mathrm{~mm}$ of displacement, more deformation is concentrated throughout the restraining bend. The maximum shear rate in the releasing bend shifts towards the south and, most interestingly, is dissipated in the central part (Fig. 8g).

In general, through its evolution, the model shows that most of the shear strain was concentrated along the two edges of the model Cinarcik segment, with strong drops at its centre. Moreover, it suggests that maximum topographic changes, i.e., the stronger permanent deformations, are the result of strain concentrations at the bending points, while the reduction of the shear rate along the releasing and restraining bends might be the result of strain diffusion (Fig. 8a). The equivalent of the Cinarcik segment shows that slow deformation corresponds to topographic uplift, but compression only marks the edge of the uplifted area. In contrast, extension and subsidence above the releasing bend is accommodated by a narrow asymmetric depression (Fig. 8b, e, h).

\section{Discussion}

\subsection{Experimental limitations}

Before exploring how the analogue models correlate with marine geological/geophysical data, we should underline their possible limitations. First of all, a typical limiting factor in sandbox modelling is the lack of fluids permeating the "experimental" crust, both in host rock pores and localised within shear zones. It is known that pore fluid pressure is a major factor that shapes deformation patterns and fault activity in nature (e.g., Chester et al., 1993). In our case, being the Cinarcik fault segment below sea water, fluid percolation could play a key role in reducing the effective stress along the fault. Other significant oversimplifications in the sandbox experiments are also their lack of a 
geothermal gradient, of mineral reactions constraining rock rheology variations, and of an isostatic and flexural response to tectonic deformation. A specific feature of most experiments that simulate strikeslip faulting is localization of the master shear zone at a sharp boundary between nondeformable and mobile basal plates. In our model, we used a $2 \mathrm{~mm}$-thick silicone layer, scaled to the relative thickness of the viscous lower crust as suggested by Kende et al. (2017). The thickness and viscosity of this layer controls how efficiently basal displacement is transferred to the shallower crust. Crustal heterogeneities were also not incorporated into the model, and this should be considered when comparing the experiments to nature. The experimental crust is, in fact, assumed to be mechanically homogeneous, without heterogeneities or inheritances that might influence deformation patterns. For example, heterogeneities in the crust deformed by the NAF system have been proposed to play an important role in strain localization (Le Pichon et al., 2016). Moreover, our model does not include the effects of sedimentation, while in nature the Cinarcik Basin has 4-6 km of sedimentary infill that is likely to consist of Pliocene-Quaternary syn-kinematic sediments (Carton et al., 2007). Finally, the shape of the master strike-slip right-lateral fault system in the experiments is simplified with respect to nature (Fig. 4a).

In this study, where the strain accumulation was directly linked along different segments of the fault, another limitation is the lack of distinction between elastic and anelastic deformation. Since we are dealing with restraining and releasing bends, topographic changes are able to record permanent deformations, as well as their intensity and nature, while this would not be possible in a pure strike-slip kinematic environment. Given the above, the purpose of our modelling was not to exactly reproduce the geometries of the real world, but rather to verify whether a simple geometry imposed as an initial condition in the model was able to account for the strain distribution observed along this complex tectonic system.

\subsection{Bending points as stress barriers: comparison between the model and the natural case}

The analogue experiment, with a releasing and restraining bend pair along a segmented transform fault, shows that the bending points represent indeed a "transition" in terms of the strain rate and character of the observed deformation pattern. The model shows relatively "slow" shear along the releasing and restraining bend pair. In contrast, the eastern and western east-west parallel segments, with "pure" strike-slip displacements, are characterised by relatively high shear rates. Despite their slower shear rate, the topographic response on the releasing and restraining pairs is significant, with the generation of subsidence and uplift over wide areas, and with the generation of high morphological gradients (Fig. 8h). In the model counterpart to the extending Cinarcik segment, for example, strain partitioning results in the formation of a basin, i.e., a permanent topographic depression. So, since strain is able to be transferred from the eastern pure strike-slip segment to the depocenter of the basin, the bending point cannot be considered a stress barrier, but rather a point where strain spreads out and diffuses. This characteristic seems to increase with the amount of displacement up to the centre of the extending Cinarcik segment, where differences across surrounding structures are not measurable (Fig. 8g). Nevertheless, the total strain in this region may still be constant. In fact, the areal strain pattern in our model shows that deformation involves a wider region compared to the pure strike-slip segment to the east of Tuzla Bend, and that deformation increases in the area characterised by negligible strain rate (Fig. 8i). Interestingly, this area in the model corresponds to one of the most debated areas of the Sea of Marmara, where both fault kinematic and strain accumulation along the faults is discussed, as it is considered the next segment that will rupture after the Izmit 1999 event, in the assumed westward-migrating earthquake sequence (Parsons et al., 2000; King et al., 2001; Uçarkuș et al., 2011; Bohnhoff et al., 2013). Most studies agree that the strike-slip motion characterising the eastern part of the NAF before entering the Gulf of Izmit, changes into transtension as it reaches the Cinarcik basin (Armijo et al., 2002; Le Pichon et al., 2003; Carton et al., 2007). This interpretation is also confirmed by the analysis of seismic reflection profiles presented in this paper, clearly showing the transition from a focused, mostly strike-slip shear east to the eastern bending point (Section A-A' in Fig. 3), to the wider mostly normal shear in the centre of the basin (Section B-B' in Fig. 3). This observation is supported by the experimental results that indicate a transition from concentrated to diffuse shear, but not to the presence of a barrier to the westward propagation of strain.

Further extrapolation of our results would suggest that seismic slip occurring to the east of the bend would increase elastic strain accumulation on the adjacent segment to the west, but this strain might be partitioned over a wide area. Our experiments are not able to discriminate whether strain could be dissipated through aseismic creep or small seismic events. Subsidence might be facilitated because complete elastic rebound in normal faults is inhibited by gravity, so that permanent deformation accumulates with time (Carton 2003; Hirn and Team, 2003; Seeber et al., 2004; Pondard et al., 2007). The experiments suggest that if elastic strain is involved, it accumulates at a slower rate in transtensional faults than in strike-slip segments. Therefore, the normal faulting at the edges of the Cinarcik basin might involve several seismic cycles of the adjacent strike-slip fault segment to reach a critical stress state. This would imply significative differences in seismic cycles between the Izmit and Cinarcik segments of the NAF. Thus, if the Tuzla Bend is able to transfer shear stress towards the west, it appears that it would be distributed into several fault strands, affecting the earthquake magnitudes and recurrence time intervals along the Cinarcik segment, that would be less effective in accumulating and releasing tectonic loads in comparison to the Izmit segment.

Many geological and geodetic observations document evidence of the impact of fault bends and associated folding on earthquake cycles (Suppe, 1983; Shaw et al., 2005; Sathiakumar et al., 2020). In the case of San Andreas Fault, slip partitioning because of the restraining Big Bend and the loading of buried faults below the Los Angeles metropolitan area might have an impact on earthquake cycles (Li and Liu, 2007; Li et al., 2009; Daout et al., 2016). Similarly, the Lebanese restraining bend along the Dead Sea Fault Zone seems to be responsible for partitioned crustal deformation into NNE-SSW strike slip faults and regional WNW-ESE crustal shortening that involves distinct sets of earthquakes in different striking faults (Gomez et al., 2007).

\subsection{The compressive deformations of the NW edge of the Cinarcik basin}

The NW edge of the Cinarcik basin is the site of a topographic high characterised by evidence of folding and compressive deformation. To highlight this pattern, we combined the morphobathymetric map of the Cinarcik basin area (slope map in the background) with the elevation map resulting from the analogue model at the end of the experiment (Fig. 9). Scaling between the two representations was carried out by using as a reference the position and length of the NAF-N principal deformation zone. The transtensional deformation pattern of the model, characterised by negative topography (the blue colour in the topographic change panel in Fig. 8), overlaps with the deepest portion of the Cinarcik basin, while the red pattern, highlighting the generation of positive relief in a region of overall compressive deformation in Fig. 8, is concentrated immediately to the west of the Istanbul Bend. We note that the geometrical conditions imposed to the model, although very simple, account surprisingly well for the observed regional deformation pattern, both in its nature and scaled magnitudes. However, since bathymetry can be affected by surficial processes (gravitative instability, erosion, currents, sediment deposition, etc.) rather than deformation caused by deep-seated faults, the comparison between the model and the nature of deformation should consider the subsurface images, such as seismic reflection profiles described in paragraph 2.1. 


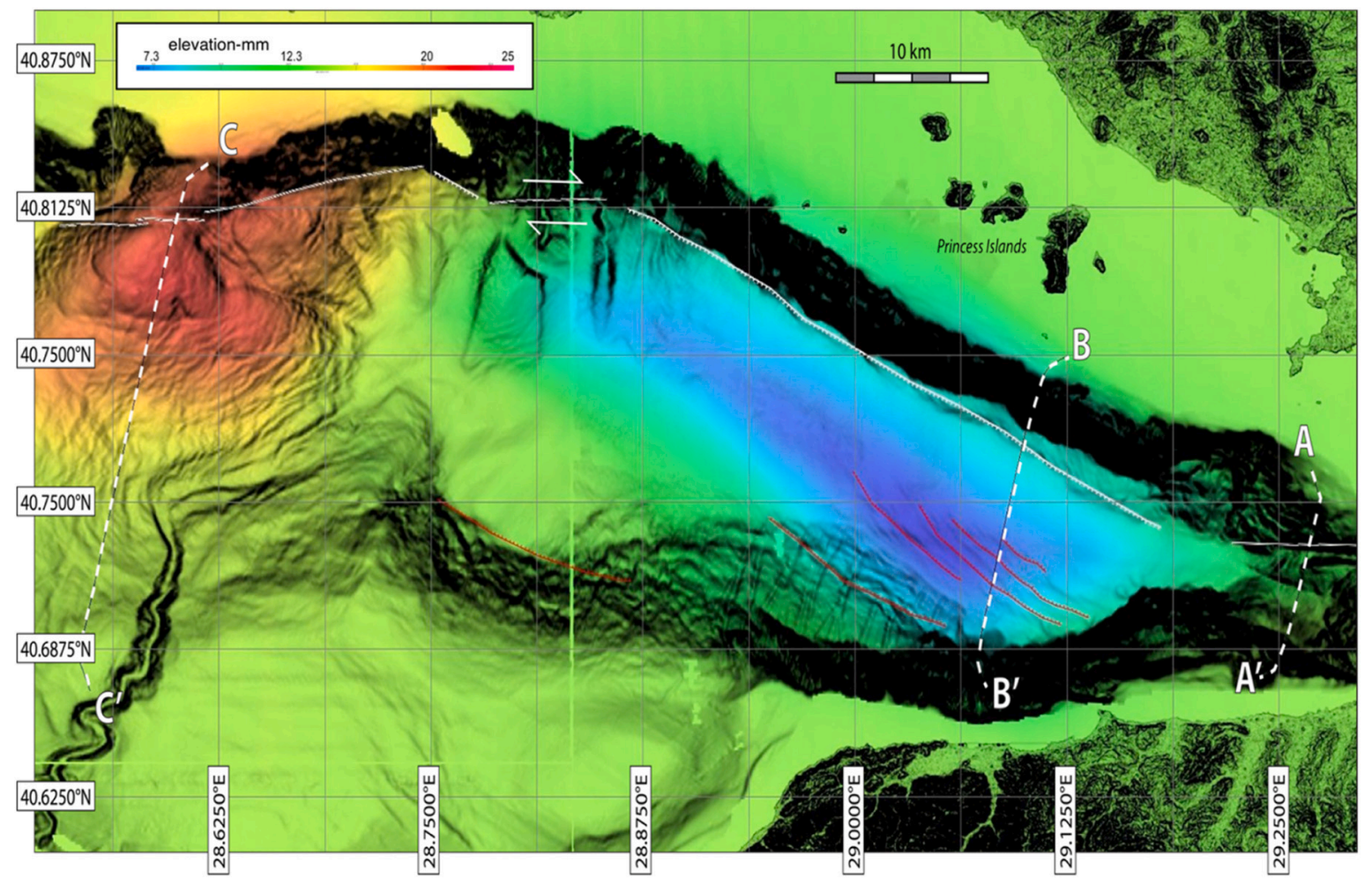

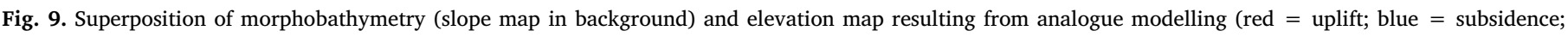

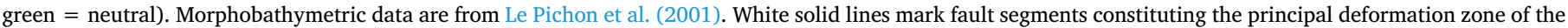

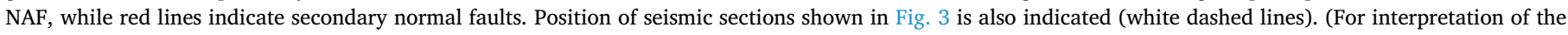
references to colour in this figure legend, the reader is referred to the web version of this article.)

Starting from the east, both the model and geophysical data show a narrow through resulting from a sub-vertical trace of the fault (Figs. 2, $7 \mathrm{a})$. In the model, in fact, the northern boundary fault of the basin is steeply dipping, which correlated well with the geometry of the fault at the margin of (Carton et al., 2007). Moving to the west, in the centre of the Cinarcik Basin, the features imaged along the seismic profiles and the model show similar deformation patterns (Fig. 3b and Fig. 7b), with an important component of extension being the characteristic of this segment of the fault (Fig. 9). The seismic profile shows that the change in dip orientation of the major fault plays a key role in the morphology of the basin, that becomes wide and deep, but with asymmetric slope angles. The model shows that this change is compatible with a small $30^{\circ}$ - diversion of the trace of the main fault. The resulting morphology of the basin is also well matched, with the northern side of the basin steeper and therefore more prone to gravitational instability of sediments than the opposite side.

Finally, compressional deformation characterizes the western half of the Cinarcik basin to the west of the so-called Istanbul Bend (Fig. 2). In both the model and real world, the western half of the depression becomes narrower and shallower towards the west. The model also correlates well with the NE-SW trending morphobathymetric uplift of the Central High. The orientation of the main fault changes again to a vertical trace in both the model and the Cinarcik basin (Fig. 7c). The comparison between experimental results and seismic interpretations carried out on available seismic lines strengthens the idea that a restraining bend adjacent to a releasing bend with a difference of $\sim 10^{\circ}$ in orientation might produce a change in width of the basin, a topographic high with the characteristics observed in the NW Cinarcik basin, and changes in fault orientations as observed along the tectonic boundary (Fig. $7 \mathrm{c}$ ). This would support the idea that the formation of the Central High with its $\sim 400 \mathrm{~m}$ relief may be controlled by the interaction of the restraining bend and the master fault at depth. The model also suggests that this relief may be related to the characteristics of the fault at depth, where the lower crust appears to be deformed and mobilized by the fault and by flower style branching faults cut the entire crust.

\section{Conclusions}

The Cinarcik basin, a tectonic depression along the North Anatolian Fault in the Sea of Marmara, is bounded in its northern edge by a seismogenic fault that connects the Istanbul metropolitan area to the Izmit fault segment which ruptured in 1999 during a Mw 7.4 earthquake. We successfully reproduced tectonic deformations in this area with a simple analogue model characterised by a velocity discontinuity imposed at its base by a moving basal plate that has an edge profile which reproduces the shape of the principal displacement zone of the North-Anatolian Fault in this sector. As displacements are slowly applied at the base of the model, a first principal shear zone forms along the velocity discontinuity, with associated growth of horst and graben deformation patterns above the restraining and releasing bend segments, respectively. The model layout is able to reproduce the main characteristics of the Cinarcik basin, both in terms of its fault kinematics and morphology. This led us to analyse the transfer of stress between the different fault segments. We propose that the Izmit segment can transfer strain to the Cinarcik segment, as most probably happened after the 1999 earthquake. However, the partitioning of deformation from strike-slip to transtension, moving from the Izmit to the Cinarcik segment, may induce slower strain accumulation in this latter, resulting in a longer seismic-cycle for earthquakes of similar magnitude. This conclusion might suggest a general delay for earthquakes occurring on the Cinarcik segment that will be eventually triggered by tectonic loading from the east. Our results also suggest that most of deformation observed along the North-Anatolian Fault between the rupture termination of the Izmit 1999 earthquake and the Istanbul metropolitan area is controlled by the change in geometry of the fault segments. In particular, compressive deformation observed at the 
connection between the Cinarcik and the Central High segments was reproduced in the model by imposing a small - $10^{\circ}$ - sharp change in the relative orientations of the segments. We suggest that this change in orientation could reflect the presence of inherited geological heterogeneities cut by the NAF along the complex suture that constitutes this margin, particularly in the Sea of Marmara region.

\section{Declaration of competing interest}

The authors declare that they have no known competing financial interests or personal relationships that could have appeared to influence the work reported in this paper.

\section{Acknowledgments}

We thank Associate Editor Ramon Carbonell, and anonymous reviewers for their constructive feedback that helped improve the quality of the manuscript. This work was fostered by visits funded by the FLOWS-COST Action ES1301 "FLOWS" (EU-COST ES 1301). Analogue models were produced in the Analogue Modelling Laboratory "E. Costa" of the Department of Chemistry, Life Sciences and Environmental Sustainability, University of Parma, Italy. We thank J. P. Morgan for his help with the science and writing.

The seismic reflection profiles are part of the SEISMARMARA cruise dataset and are downloaded from the IFREMER web site (https:// campagnes.flotteoceanographique.fr). The MATLAB code for geological models is available on the Zenodo, open-access repository web-site (https://doi.org/10.5281/zenodo.3597335). We would like to thank Pierre Henry for contributing in our code to analyse our dataset.

All other sources used to build to geological models are published and referenced in the manuscript. Input files necessary to reproduce the model are available from the authors upon request (Sibel.Bulkan. 2015@live.rhul.ac.uk).

\section{References}

Adam, J., Lohrmann, J., Hoth, S., Kukowski, N., Oncken, O., 2002. Strain variation and partitioning in thrust wedges: high-resolution data from scaled sandbox experiments by 2D-3D PIV analysis. Boll. Geofis. Teor. Appl. 42, 123-125.

Aslan, G., Lasserre, C., Cakir, Z., Ergintav, S., Özarpaci, S., Dogan, U., ... Renard, F., 2019. Shallow creep along the 1999 Izmit Earthquake rupture (Turkey) from GPS and high temporal resolution interferometric synthetic aperture radar data (2011-2017). Journal of Geophysical Research: Solid Earth 124 (2), 2218-2236.

Adam, J., Urai, J.L., Wieneke, B., Oncken, O., Pfeiffer, K., Kukowski, N., Schmatz, J., 2005. Shear localisation and strain distribution during tectonic faulting - new insights from granular-flow experiments and high-resolution optical image correlation techniques. J. Struct. Geol. 27 (2), 283-301.

Ambraseys, N., 2002. The seismic activity of the Marmara Sea region over the last 2000 years. Bull. Seismol. Soc. Am. 92, 1-18.

Armijo, R., Meyer, B., Hubert, A., Barka, A., 1999. Westward propagation of the North Anatolian fault into the northern Aegean: timing and kinematics. Geology 27, 267-270.

Armijo, R., Meyer, B., Navarro, S., King, G., Barka, A.A., 2002. Asymmetric slip partitioning in the Sea of Marmara pull-apart: a clue to propagation processes of the North Anatolian Fault? Terra Nova 14, 80-86. https://doi.org/10.1046/j.1365-3121.2002. 00397.x.

Barka, A.A., Kadinsky-Cade, K., 1988. Strike-slip fault geometry in Turkey and its influence on earthquake activity. Tectonics 7, 663-684. https://doi.org/10.1029/ TC007i003p00663.

Baştürk, Nilay Başarır, Meral Ozel, Nurcan, 2020. Seismic parameters re-determined from Historical Seismograms of 1935-Erdek- Marmara Island and 1963-Çınarcık Earthquakes.

Bécel, A., Laigle, M., de Voogd, B., Hirn, A., Taymaz, T., Galvé, A., ... Özalaybey, S., 2009. Moho, crustal architecture and deep deformation under the North Marmara Trough, from the SEISMARMARA Leg 1 offshore-onshore reflection-refraction survey. Tectonophysics 467 (1-4), 1-21.

Bécel, A., Laigle, M., De Voogd, B., Hirn, A., Taymaz, T., Yolsal-Cevikbilen, S., Shimamura, H., 2010. North Marmara Trough architecture of basin infill, basement and faults, from PSDM reflection and OBS refraction seismics. Tectonophysics 490 (1-2), 1-14.

Bohnhoff, M., Bulut, F., Dresen, G., Malin, P.E., Eken, T., Aktar, M., 2013. An earthquake gap south of Istanbul. Nat. Commun. 4, 1999.

Bulkan, S., 2020. Geological and Kinematic Evolution of the Western Part of the North Anatolian Fault System: An Analogue Modelling Investigation. Thesis. Royal
Holloway, University of London.

Cakir, Z., Ergintav, S., Özener, H., Dogan, U., Akoglu, A.M., Meghraoui, M., Reilinger, R, 2012. Onset of aseismic creep on major strike-slip faults. Geology 40 (12), 1115-1118.

Carton, H. (2003). Structure of the Cinarcik Basin (eastern Marmara Sea) from denselyspaced multi-channel reflection profiles. Lithos Science Report.

Cappelletti, A., Tsikalas, F., Nestola, Y., Cavozzi, C., Argnani, A., Meda, M., Salvi, F., 2013. Impact of lithospheric heterogeneities on continental rifting evolution: constraints from analogue modelling on South Atlantic margins. Tectonophysics 608, 30-50.

Carton, H., Singh, S.C., Hirn, A., Bazin, S., De Voogd, B., Vigner, A., ... Sevilgen, V., 2007. Seismic imaging of the three-dimensional architecture of the Cinarcik basin along the North Anatolian fault. J. Geophys. Res. Solid Earth 112 (B6).

Chester, F.M., Evans, J.P., Biegel, R.L., 1993. Internal structure and weakening mechanisms of the San Andreas Fault. J. Geophys. Res. 98 (B1), 771-786. https://doi. org $/ 10.1029 / 92 J B 01866$.

Cunningham, W.D., Mann, P., 2007. Tectonics of strike-slip restraining and releasing bends. Geol. Soc. Lond., Spec. Publ. 290 (1), 1-12.

D’Adda, P., Longoni, R., Magistroni, C., Meda, M., Righetti, F., Cavozzi, C., Nestola, Y., Storti, F., 2016. Extensional reactivation of a deep transpressional architecture: insights from sandbox analogue modeling applied to the Val d'Agri basin (Southern Apennines, Italy). Interpretation 5, 55-66.

D’Adda, P., Longoni, R., Magistroni, C., Meda, M., Righetti, F., Cavozzi, C., ... Storti, F., 2017. Extensional reactivation of a deep transpressional architecture: Insights from sandbox analogue modeling applied to the Val d'Agri basin (Southern Apennines, Italy). Interpretation 5(1) (2), SD55-SD66.

Daout, S., Barbot, S., Peltzer, G., Doin, M.P., Liu, Z., Jolivet, R., 2016. Constraining the kinematics of metropolitan Los Angeles faults with a slip-partitioning model. Geophys. Res. Lett. 43 (21), 11-192.

Ergintav, S., Reilinger, R.E., Çakmak, R., Floyd, M., Cakir, Z., Doğan, U., King, R.W., McClusky, S., Özener, H., 2014. Istanbul's earthquake hot spots: Geodetic constraints on strain accumulation along faults in the Marmara seismic gap. Geophys. Res. Lett. 41, 5783-5788. https://doi.org/10.1002/2014GL060985.

Gasperini, L., Stanghellini, G., 2009. SeisPrho: an interactive computer program for processing and interpretation of high-resolution seismic reflection profiles. Comput. Geosci. 35, 1497-1507.

Gasperini, L., Polonia, A., Çağatay, M.N., Bortoluzzi, G., Ferrante, V., 2011a. Geological slip rates along the North Anatolian Fault in the Marmara region. Tectonics 30, C6001. https://doi.org/10.1029/2011TC002906.

Gasperini, L., Polonia, A., Bortoluzzi, G., Henry, P., Le Pichon, X., Tryon, M., Çağatay, M.N., Geli, L., 2011b. How far did the surface rupture of the1999 Izmit earthquake reach in Sea of Marmara. Tectonics 30https://doi.org/10.1029/2010TC002726. TC1010.

Gomez, F., Karam, G., Khawlie, M., McClusky, S., Vernant, P., Reilinger, R., ... Barazangi, M., 2007. Global Positioning System measurements of strain accumulation and slip transfer through the restraining bend along the Dead Sea fault system in Lebanon. Geophysical Journal International 168 (3), 1021-1028.

Görür, N., Cağatay, M.N., 2010. Geohazards rooted from the northern margin of the Sea of Marmara since the late Pleistocene: a review of recent results. Nat. Hazards 54 (2), 583-603.

Grall, C., Henry, P., Tezcan, D., Mercier de Lepinay, B., Bécel, A., Géli, L., Harmegnies, F., 2012. Heat flow in the Sea of Marmara Central Basin: possible implications for the tectonic evolution of the North Anatolian fault. Geology 40 (1), 3-6.

Grall, C., Henry, P., Thomas, Y., Westbrook, G.K., Çağatay, M.N., Marsset, B., Saritas, H., Cifçi, G., Géli, L., 2013. Slip rate estimation along the western segment of the Main Marmara Fault over the last 405-490 ka by correlating mass transport deposits. Tectonics 32, 1-15.

Hirn, Alfred, Singh, Satish, 2001. SEISMARMARA Cruise. RV Le Nadir. https://doi.org/ $10.17600 / 1080050$.

Hirn, A., Team, S., 2003. Elements of structure at crustal scale under the Sea of Marmara from multichannel seismics of the SEISMARMARA survey. EAEJA 13126.

Hubert-Ferrari, A., Barka, A., Jacques, E., Nalbant, S.S., Meyer, B., Armijo, R., ... King, G.C., 2000. Seismic hazard in the Marmara Sea region following the 17 August 1999 Izmit earthquake. Nature 404 (6775), 269-273.

Kende, J., Henry, P., Bayrakci, G., Özeren, M.S., Grall, C., 2017. Moho depth and crustal thinning in the Marmara Sea region from gravity data inversion. J. Geophys. Res. Solid Earth 122 (2), 1381-1401.

King, G.C., Hubert-Ferrari, A., Nalbant, S.S., Meyer, B., Armijo, R., Bowman, D., 2001 Coulomb interactions and the 17 August 1999 Izmit, Turkey earthquake. Comptes Rendus de l'Académie des Sciences-Series IIA-Earth and Planetary Science 333 (9), 557-569.

Klinkmüller, M., Schreurs, G., Rosenau, M., Kemnitz, H., 2016. Properties of granular analogue model materials: a community wide survey. Tectonophysics 684, 23-38.

Kurt, H., et al., 2013. Steady late quaternary slip rate on the Cinarcik section of the North Anatolian fault near Istanbul, Turkey. Geophys. Res. Lett. 40, 4555-4559. https:// doi.org/10.1002/grl.50882.

Laigle, M., Becel, A., de Voogd, B., Hirn, A., Taymaz, T., Ozalaybey, S., 2008. A first deep seismic survey in the Sea of Marmara: deep basins and whole crust architecture and evolution. Earth Planet. Sci. Lett. 270 (3-4), 168-179.

Le Pichon, X., Sengör, A.M.C., Demirbağ, E., Rangin, C., Imren, C., Armijo, R., ... Saatçılar, R., 2001. The active main Marmara fault. Earth and Planetary Science Letters 192 (4), 595-616.

Le Pichon, X., Rangin, N., Chamot-Rooke, C., Sengör, A.M.C., 2003. The North Anatolian Fault in the Sea of Marmara. J. Geophys. Res. 108 (B4), 2179.

Le Pichon, X., Şengör, A.C., Kende, J., İmren, C., Henry, P., Grall, C., Karabulut, H., 2016. Propagation of a strike-slip plate boundary within an extensional environment: the 
westward propagation of the North Anatolian Fault. Can. J. Earth Sci. 53 (11) 1416-1439.

Li, Q., Liu, M., 2007. Initiation of the San Jacinto fault and its interaction with the San Andreas fault: insights from geodynamic modeling. Pure Appl. Geophys. 164 (10), 1937-1945.

Li, Q., Liu, M., Zhang, H., 2009. A 3-D viscoelastoplastic model for simulating long-term slip on non-planar faults. Geophys. J. Int. 176 (1), 293-306.

McClusky, S., Balassanian, S., Barka, A., Demir, C., Ergintav, S., Georgiev, I., ... Kastens, K., 2000. Global Positioning System constraints on plate kinematics and dynamics in the eastern Mediterranean and Caucasus. J. Geophys. Res. Solid Earth 105 (B3), 5695-5719.

McClusky, S., Reilinger, R., Mahmoud, S., Ben Sari, D., Tealeb, A., 2003. GPS constraints on Africa (Nubia) and Arabia plate motions. Geophys. J. Int. 155 (1), 126-138.

Nestola, Y., Storti, F., Bedogni, E., Cavozzi, C., 2013. Shape evolution and finite deformation pattern in analog experiments of lithosphere necking. Geophys. Res. Lett. 40 (19), 5052-5057.

Okay, A.I., Tüysüz, O., Kaya, S., 2004. From transpression to transtension: changes in morphology and structure around a bend on the North Anatolian Fault in the Marmara region. Tectonophysics 391 (1-4), 259-282.

Özeren, M.S., Cağatay, M.N., Postacioğlu, N., Sengör, A.C., Görür, N., Eriș, K., 2010. Mathematical modelling of a potential tsunami associated with a late glacial submarine landslide in the Sea of Marmara. Geo-Mar. Lett. 30 (5), 523-539.

Parsons, T., 2004. Recalculated probability of $\mathrm{M} \geq 7$ earthquakes beneath the Sea of Marmara, Turkey. J. Geophys. Res. Solid Earth 109 (B5).

Parsons, T., Toda, S., Stein, R.S., Barka, A., Dieterich, J.H., 2000. Heightened odds of large earthquakes near Istanbul: an interaction-based probability calculation. Science 288 (5466), 661-665.

Pondard, N., Armijo, R., King, G.C., Meyer, B., Flerit, F., 2007. Fault interactions in the Sea of Marmara pull-apart (North Anatolian Fault): earthquake clustering and propagating earthquake sequences. Geophys. J. Int. 171 (3), 1185-1197.

Sathiakumar, S., Barbot, S., Hubbard, J., 2020. Earthquake cycles in fault-bend folds. J. Geophys. Res. Solid Earth 125, e2019JB018557. https://doi.org/10.1029/ 2019JB018557.

Seeber, L., Emre, O., Cormier, M.-H., Sorlien, C.C., McHugh, C.M.G., Polonia, A., Ozer, N., Cagatay, N., 2004. Uplift and subsidence from oblique slip: the Ganos-Marmara bend and the North Anatolian Transform, western Turkey. Tectonophysics 391, 239-258. Seeber, L., Cormier, M.H., McHugh, C., Emre, O., Polonia, A., Sorlien, C., 2006. Rapid subsidence and sedimentation from oblique slip near a bend on the North Anatolian transform fault in the Marmara Sea, Turkey. Geology 34 (11), 933-936.

Seeber, L., Sorlien, C., Steckler, M., Cormier, M.H., 2010. Continental transform basins: why are they asymmetric? EOS Trans. Am. Geophys. Union 91 (4), 29-30.

Şengör, A.M.C., Tuysuz, O., Imren, C., Sakınc, M., Eyidogan, H., Gorur, N., Le Pichon, X., Rangin, C., 2005. The North Anatolian fault: a new look. Annu. Rev. Earth Planet. Sci. 33, 37-112.

Shaw, J.H., Connors, C.D., Suppe, J. (Eds.), 2005. Seismic Interpretation of Contractional Fault-Related Folds: An AAPG Seismic Atlas. Vol. 53 American Association of Petroleum Geologists, Tulsa.

Smith, A.D., Taymaz, T., Oktay, F., Yuce, H., Alpar, B., Basaran, H., ... Simsek, M., 1995. High-resolution seismic profiling in the Sea of Marmara (northwest Turkey): Late Quaternary sedimentation and sea-level changes. Geological Society of America Bulletin 107 (8), 923-936.

Sorlien, C.C., Akhun, S.D., Seeber, L., Steckler, M.S., Shillington, D.J., Kurt, H., ... İmren, C., 2012. Uniform basin growth over the last 500 ka, North Anatolian Fault, Marmara Sea, Turkey. Tectonophysics 518, 1-16.

Suppe, J., 1983. Geometry and kinematics of fault-bend folding. Am. J. Sci. 283 (7), 684-721.

Thielicke, W., Stamhuis, E.J., 2014. PIVlab - towards user-friendly, a ordable and accurate digital particle image velocimetry in MATLAB. Journal of Open Research Software 2 https://doi.org/10.5334/jors.bl. e30.

Uçarkuş, G., Cakir, Z., Armijo, R., 2011. Western termination of the Mw 7.4, 1999 İzmit Earthquake rupture: implications for the expected large earthquake in the Sea of Marmara. Turk. J. Earth Sci. 20 (4), 379-394.

White, D.J., Take, W.A., Bolton, M.D., Munachen, S.E., 2001. A deformation measurement system for geotechnical testing based on digital imaging, close-range photogrammetry, and PIV image analysis. In: Proceedings of the International Conference on Soil Mechanics and Geotechnical Engineering. Vol. 1. AA Balkema Publishers, pp. 539-542.

Wolf, H., König, D., Triantafyllidis, T., 2003. Experimental investigation of shear band patterns in granular material. J. Struct. Geol. 25 (8), 1229-1240. 